\title{
Severe postural hypotension following home canoe construction from polyester resins
}

\author{
I. A. MACFARLANE \\ M.D., M.R.C.P.
}

\author{
R. WILKINSON \\ Ph.D., M.R.C.P.
}

\author{
J. M. HARRINGTON* \\ M.D., F.R.C.P. \\ The Diabetic Clinic, General Hospital Birmingham B4 $6 \mathrm{NH}$ and *Department of Occupational Health, Medical \\ School, Birmingham
}

\section{Summary}

On two occasions a 36-year-old man developed severe postural hypotension and neurological signs after working with a polyester resin canoe building kit in an unventilated shed. It is likely that his recurrent illness was caused by styrene intoxication. Postural hypotension secondary to styrene exposure has not previously been reported.

KEY WORDS: conjunctivitis, syncope.

\section{Introduction}

'Do-it-yourself' canoe building kits using polyester resins are now widely available. Styrene vapour is given off from the resin during the moulding process and adequate air extraction or ventilation facilities are necessary to prevent a build-up of styrene to toxic concentrations. This report describes a man who presented twice with severe postural hypotension and neurological signs after working with a canoe building kit at home.

\section{Case report}

A 36-year-old man was admitted to hospital with a 5-day history of dizziness and episodes of loss of consciousness on standing. For 2 days he was confined to bed with these symptoms and was also incontinent of faeces. He was confused on admission but not dehydrated with a resting heart rate of 55 per min. Systolic blood pressure was $110 \mathrm{mmHg}$ falling to $60 \mathrm{mmHg}$ on standing with a heart rate of $62 / \mathrm{min}$. Diastolic blood pressure was unrecordable. After 48 $\mathrm{hr}$ he was alert and orientated with no abnormal neurological signs. His blood pressure was then $120 / 80 \mathrm{mmHg}$ with no postural fall. There was no history of drug ingestion. The serum sodium, potassium, urea, creatinine and blood sugar were normal on admission and after $48 \mathrm{hr}$ a Synacthen test showed a normal increase in plasma cortisol.

He was readmitted 6 weeks later with similar problems. He was again confused, with dizziness and loss of consciousness on standing. The blood pressure was $110 / 80 \mathrm{mmHg}$ lying and fell to $80 \mathrm{mmHg}$ systolic with no recordable diastolic pressure on standing. He had conjunctivitis, slurred speech, lateral and upward gaze nystagmus and limb ataxia. After $\mathbf{4 8 ~ h r}$ all abnormal physical signs had gone. On this admission a history was obtained of canoe construction from polyester resins the evening before he became ill. He had been working for 4-5 hr in a poorly ventilated shed. The canoe kit contained a general purpose water resistant resin, a thixotropic water resistant gelcoat, a liquid catalyst (methyl ethyl ketone peroxide) and fibreglass. After $1 \mathrm{hr}$ he had felt dizzy and nauseated with conjunctival irritation but had persevered for a further 3-4 hr with several breaks of 5-10 min in the fresh air. He had been working with the same materials on the evening before he became ill 6 weeks previously.

\section{Discussion}

On both occasions this patient had been working with polyester resins before he became ill. Because of poor ventilation of the work area he would have been exposed to high concentrations of styrene vapour (Toxicity Review: Styrene, 1981). Data from the manufacturers of the canoe kit indicate that styrene is the only vapour given off in significant quantities. Concentrations found $7.5 \mathrm{~cm}$ above the centre of a $75 \times 75 \mathrm{~cm}$ laminate are $60-70 \mathrm{ppm}$ in the first hour. Unfortunately urinary mandelic acid estimations, the major metabolite of styrene, were not performed during the admissions to hospital. However, it is 
highly likely that his recurrent illness was caused by styrene intoxication.

Human volunteers exposed to $376 \mathrm{ppm}$ styrene vapour developed eye and nasal irritation followed by nausea, headache, decreased dexterity and incoordination within 1 hour (Stewart et al., 1968). Rats exposed to air saturated with styrene vapour survived a 2-hr exposure but half died within $4 \mathrm{hr}$ (Hine et al., 1981). The odour threshold of styrene is $0.1 \mathrm{ppm}$. This disagreeable odour makes the inhalation of acute toxic quantities unlikely. However when exposure to styrene vapour at $376 \mathrm{ppm}$ was continued for longer than $3 \mathrm{hr}$ the nausea, headache, eye and nose irritation subsided in human volunteers and the perception of the odour diminished (Stewart et al., 1968). Our patient also found that by perseverance the nausea and conjunctival irritation diminished and he continued working.

A literature search reveals that postural hypotension as a presenting feature of styrene intoxication has not previously been reported. It was probably due to central nervous system autonomic dysfunction which has been noted (Hine et al., 1981). This may partly explain the dizziness experienced by some $\stackrel{\mathbb{Q}}{\stackrel{2}{ }}$

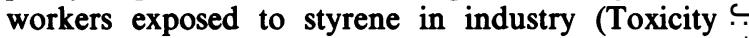
Review: Styrene, 1981). Polyester resins are now frequently used in schools and youth clubs. This case illustrates the importance of adequate ventilation of the work area.

\section{Acknowledgment}

We thank Dr M. G. FitzGerald for his permission to report this case.

\section{References}

Hine, C., Rowe, V.K., White, E.R., Darmer, K.I. \& YoungBLOOD, G.T. (1981) Epoxy compounds in Patty's Industrial Hygiene \& Toxicology, Vol $2 A$ (Ed. G. D. Clayton, 3rd rev. edn. p. 2141. Interscience, New York.

Stewart, R.D., DodD, H.C., Baretta, E.D. \& Schaffer, A.W. O (1968) Human exposure to styrene vapour. Archives of Environmental Health, 16, 656.

TOXICITY REviEw: STYRENE (1981) Health \& Safety Executive, HMSO, London. p. 1.

(Accepted 15 June 1983) 